\title{
Isolation and characteristics of cellulolytic bacteria based on corn waste as a fibrous feed bioactivator
}

\author{
S Wahyuni, Yunilas, E Mirwandhono, M Tafsin, I Sembiring \\ Animal Production Program Study, Faculty Of Agriculture, University Of North \\ Sumatera, Medan 20155, Indonesia \\ E-mail: Yunilas11@yahoo.co.id
}

\begin{abstract}
Corn waste is an agricultural product that has the potential to be used as animal feed. The aims of this study was to isolate corn waste bacteria and look for the degradation ability of bacterial fiber of corn waste as a fibrous feed bioactivator. This study was conducted in livestock production laboratory of livestock study program in faculty of agriculture, university of north Sumatra, period March to June 2018. This study used corn waste (corncob, corn straw, corn clobot, corn stalks, and corn root). Research methods used pour plate isolate methods. Parameters observed are macroscopic morphology (colony form, colony color, the edge of the colony, and colony elevesi), microscopic morphology (cell shape and gram coloring), and test the ability to degrade fiber in bacteria.

The isolation result obtained 8 isolates with varied shapes and there are 6 isolates that have ability to degrade fibers in bacteria include B2, B3, B4, B5, B6, B7. The conclusion of this study were obtained 8 cellulolytic bacteria isolates and B3 has a high potential to degrade the fiber.
\end{abstract}

\section{Introduction}

Corn waste is an agricultural product that has the potential to be used as animal feed. The waste produced from corn plants is corn straw (stover), corn fruit bark (klobot), and corn cobs which are usually not used anymore or the economic value is very low. From the BPS data of North Sumatra Province in 2016 (2016) it is known that the harvested area of corn plants is around 252.729,2 ha, as much production 1.557.462,8 tons and the average production of corn crops around 6 tons/ha. So the corn waste is the stem 3 ton/ha, corn straw 1,2 tons/ha, corn straw 0,6 tons/ha, corncob 1,2 tons/ha [1]. The use of cellulolytic microorganisme or cellulase enzymes to degrade crude fiber content can be used as an alternative to improve nutrient quality and digestibility of corn waste feed. Indigenous microorganisms are microbes derived from their own substrate which have optimal ability to degrade fibrous feed. Through indigenous microbial exploration, multi enzymes will be produced which are very instrumental in the feed processing process [2].

\section{Materials and Methods}

\subsection{Time and place of research}

The study was conducted at the Animal Production Laboratory of the Animal Husbandry Study Program, Faculty of Agriculture, University of North Sumatra. The study runs from March to June 2018

\subsection{Materials}

The material that will be used is a sample of corn waste isolates (corn stalks, corn husk, corn straw, and corn roots). General Nutrient Agar (NA) medium for purifying microorganisms. The media must be selective to grow cellulolytic bacteria during isolation in the form of a modified CMC medium [2] $0.5 \%$ peptone, $0.5 \%$ yeast extract, $1 \% \mathrm{~K} 2 \mathrm{HPO} 4,0.02 \% \mathrm{MgSO} 47 \mathrm{H} 2 \mathrm{O}, 1 \% \mathrm{Na} 2 \mathrm{CO} 3,2 \%$ agar and $1.0 \%$ (CMC, xylan, lignin, manan, respectively). The tools used are incubator, autoclave, microscope, erlenmeyer, petri disk, test tube, rack tube, pipette, micro pipette, stirrer, vortex, bunsen, glass object, measuring grille, becker glass, thermometer, $\mathrm{pH}$ meter, hot plate, scales digital, oven, caliper, digital camera 


\subsection{Methods}

The research method used is an exploratory method which begins with the creation of indigenous microorganism sources (MOL) adopting the making of microorganism sources. Isolation uses pour plate method and ability to integrate fiber using a diffusion method based on qualitative methods [3].

\subsection{Research Implementation}

Isolation of Microorganisms

Corn waste as a source of isolates was taken as much as 5 grams and then applied in $45 \mathrm{ml}$ streil distilled water containing $0.85 \%$ physiological $\mathrm{NaCL}$, then dilution series was carried out. Dilution series results were taken $1 \mathrm{ml}$ then inoculated into the medium to be selective. Petri dishes that have been poured into selective media use spread plate method. The inoculated media was incubated for 24-48 hours at 370C to observe macroscopic isolates. Growing colonies were observed microcopically including the shape, elevation, edge, color of the colony.

Purification of microorganism culture

Isolates that have grown are then purified (purified) and transferred to new Nutrient Agar (NA) growth media according to the characteristics of each colony. Colony culture grows until a single (pure) colony is obtained and allows it to be carried out in the next stage.

Enzyme Activity Test (ability to degrade fiber) Qualitatively

Testing enzyme activity for its ability to degrade fiber (lignocellulose) qualitatively [3]. Selection is done based on the highest clear zone ratio to the diameter of the colonies planted [4].

\section{Parameters observed}

Parameters observed included: Characteristics of microorganisms including macrocopical morphology test (colony shape, colony color, colony edge, colony elevation), microoptic morphology test (gram dye and cell shape), and bacterial ability to degrade fiber according to [5] and [6].

Data analysis

Research data is presented descriptively in the form of tables or drawings [7].

\section{Results and Discussion}

\subsection{Isolation of Corn Waste Bacteria}

In this study, the isolation method used was the isolation method on the media of the pouring plate [8] by taking the diluted sample and the sample which was then circulated into the media. The isolated corn waste comes from the community plantation Jl. Abdul Hakim in Medan.

After incubation for 24-48 hours, bacterial colonies were grown using pour plate method and morphology was observed. From the suspected isolation that is thought to contain cellulose enzymes, xylano enzymes, ligno enzymes are thought to have a common ability to degrade. Then it was purified with a streak quadrant method using general media on petri dishes.

In this study 8 isolates grown on selective media were found to be cellulolytic bacteria. All isolates obtained were observed macroscopic isolate characteristics and observations presented in Table.

Table 1. Characteristics of isolates macroscopically 


\begin{tabular}{|c|c|c|c|c|c|}
\hline \multirow[t]{2}{*}{ ISOLAT } & \multicolumn{5}{|c|}{ Characteristics } \\
\hline & Size & From & Colour & Elevation & Edge \\
\hline $\mathrm{B} 1$ & Medium & Circular & milky white & Convex & Undulate \\
\hline B2 & Big & Ireguler & White & Umbonate & Undulate \\
\hline B3 & Big & Ireguler & milky white & Raised & Lobate \\
\hline B4 & Small & Circular & Yellowish White & Raised & Lobate \\
\hline B5 & Small & Circular & White & Raised & Curlate \\
\hline B6 & Small & $\begin{array}{c}\text { Circular/ } \\
\text { Bundar }\end{array}$ & White & Umbonate & Undulate \\
\hline B7 & Medium & Ireguler & White & Flat & Lobate \\
\hline B8 & Small & Rhizoid & White & Flat & Curlate \\
\hline
\end{tabular}

Based on table 1 it is explained that the 8 isolates have varying characteristics. This is due to differences in the bacteria that grow each isolate which has different characteristics for each isolate. Isolates B1, B2, B3, B4, B5, B6, B7 and isolates B8. Colonies that grow macroscopically have characteristics: colonies grow like spots, oval around the media and white or beige. Colonies were seen within 24 hours of incubation at $37^{\circ} \mathrm{C}$ in an incubator. This is consistent with the statement [9] which states that morphological observations show that cellulolytic bacteria isolated from corn waste have a white / cream oval shape.

Growing bacterial colonies were observed for morphology and purified by the quadrant streak method in a common medium in petri dishes. The activity is repeated until bacterial isolates produced are single cultures. Furthermore, it was tested with gram staining which produced pink-colored coccus colonies and the observations were presented in Table 2.

Table 2. Characteristics of isolates microscopically

\begin{tabular}{lcll}
\hline No & Isolate type & Gram test & Cell from \\
\hline 1 & B1 & Negative & Kokus \\
2 & B2 & Negative & Kokus \\
3 & B3 & Negative & Kokus \\
4 & B4 & Negative & Kokus \\
5 & B5 & Negative & Kokus \\
6 & B6 & Negative & Kokus \\
7 & B7 & Negative & Kokus \\
8 & B8 & Negative & Kokus \\
\hline
\end{tabular}

Based on table 2 it is explained that these isolates are gram-negative because they can bind safranin dyes, differences in color binding in gram-negative and positive bacteria due to differences in isoeletric points of protoplasm and permeability of the cytoplasmic membrane of cell walls. The isoelectric gram-positive point is at $\mathrm{pH} 2$ while gram-negative is $\mathrm{pH} 5$, therefore gram-positive will hold alkaline dyes much stronger than gram-negative, the low isolet points of gram-positive bacteria are due to ribonucleic acid and teikoic acid [10].

After doing the characteristics of each isolate, it will be continued by measuring the semiquantitative activity of the bacteria by measuring the clear zone (CMC substrate) of each isolate, then the best isolate will be selected for each substrate by measuring the clear zone. The formation of clear zones is a sign that these isolates are able to degrade fiber components

3.2 Enzyme Activity Test (ability to degrade fiber) Qualitatively

Testing the presence of cellulolytic activity was shown by visualizing the clear zone around the colony on CMC media so that after the dye was given congo red. The medium used was a modified Carboxy Methyl Cellulosa / CMC substrate [2], which consisted of $0.5 \mathrm{gr}$ of peptone, $0.5 \mathrm{rg}$ of yeast 
agar, 1 gr of K2HPO4, 0.02 gr of $\mathrm{MgSO} 47 \mathrm{H} 2 \mathrm{O}, 1$ gr of $\mathrm{Na} 2 \mathrm{CO} 3,20$ gr agar and 0.5 gr CMC. The substrate is added to the growing media that is used as a source of carbohydrates by bacteria.

The test results showed that only eight isolates were able to produce clear zones. The ability of bacteria to produce clear zones on cellulolytic specific media indicates that bacteria are capable of producing cellulase enzymes. The magnitude of the clear zone produced in the six bacterial isolates showed a difference. This is related to the ability of each bacterial isolate to produce cellulase enzyme. Bacterial isolates which have high cellulase enzyme activity can hydrolyze cellulose to glucose and show a large clear zone around the colony. This is due to changes in the structure of the fibrous cellulose to glucose with the structure being non-fiber. CMC media which is hydrolyzed by cellulase enzyme if it is inundated by congo red dye will not be colored. This interaction takes place non-covalently. Congo red is used as an indicator of $\beta$-D-glucan degradation in the media so that [11]. In this study found 8 isolates of cellulolytic bacteria. The observations of the clear zones formed are presented in the drawing image.

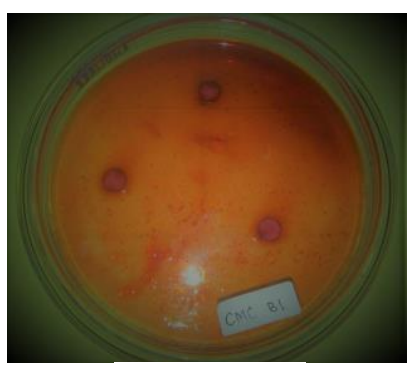

B1

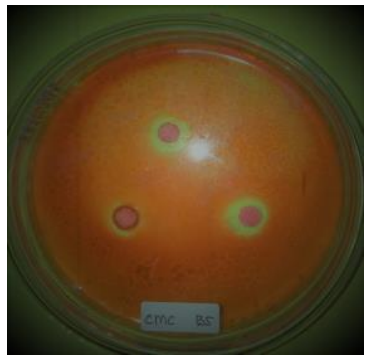

B5

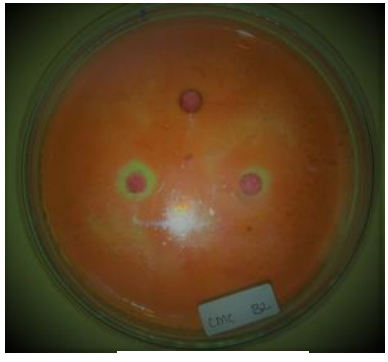

B2

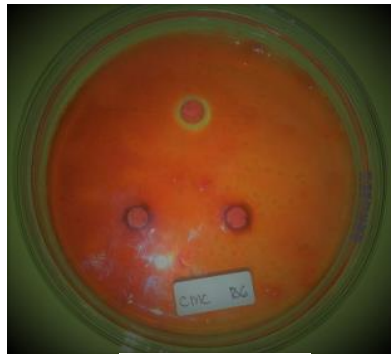

B6

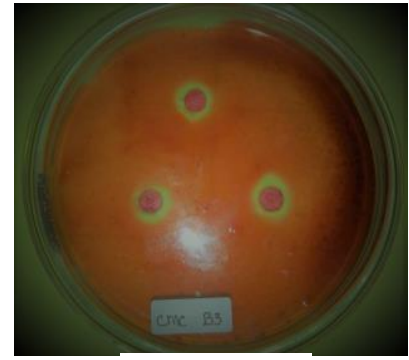

B3

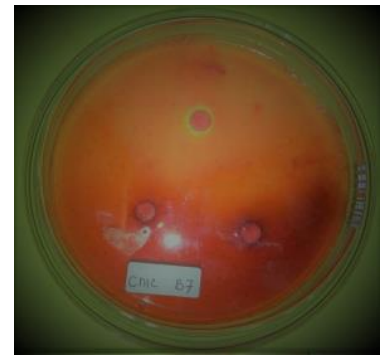

B7

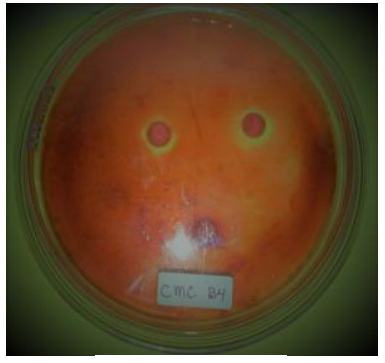

B4

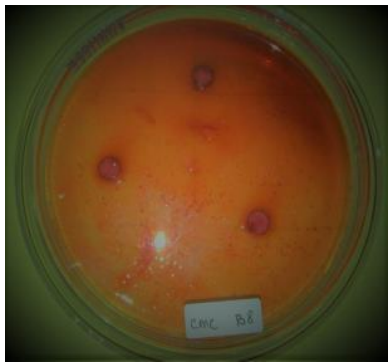

B8

Figure 1. Observation of clear zones

The results showed that eight cellulolytic bacterial isolates had the ability to degrade different fibers. This can be seen from the diameter of the clear zone formed in the medium containing the Carboxy Methyl Cellulosa / CMC substrate. The wider the clear zone formed, the higher the ability of the isolate to degrade cellulose. The results of measurements of clear zones in each isolate are presented in Table 3.

Table 3. Clear zones (cellulolytic index) isolates from corn waste (mm)

\begin{tabular}{lrcc}
\hline $\begin{array}{l}\text { Bacterial } \\
\text { Isolates }\end{array}$ & $\begin{array}{c}\text { Diameter } \\
\text { Clear Zone }\end{array}$ & Diameter Colony & Cellulolytic index \\
\hline B1 & - & - & - \\
B2 & 9,785 & 5,00 & 0,957 \\
B3 & 11,006 & 5,00 & 1,201 \\
B4 & 9,430 & 5,00 & 0,886 \\
B5 & 10,076 & 5,00 & 1,015 \\
B6 & 8,240 & 5,00 & 0,640 \\
B7 & 7,850 & 5,00 & 0,570 \\
B8 & - & - & - \\
\hline
\end{tabular}


The results showed that out of the eight isolates, two of them did not have the ability to degrade fiber with no clear zone forming on the media. Of the six isolates that formed a clear zone and the highest cellulolytic index was B3 isolate with 1,201 cellulolytic index, 1,05 mm B5 isolate, B2 isolate 0.975 $\mathrm{mm}, \mathrm{B} 4$ isolate $0.886, \mathrm{~B} 6$ isolate 0.64 and B7 with the lowest cellulolytic index $0.57 \mathrm{~mm}$. Whereas isolates B1 and B8 did not form clear zones. [12], stated that the difference in clear zone index for each isolate was because each bacterial species had the ability to produce different cellulase in hydrolyzing Carboxy Methyl Cellulosa / CMC substrates.

Cellulolytic bacterial isolates B3 showed the highest cellulolytic activity compared to other isolates. These isolates include potential fiber degrading isolates compared to other isolates. According to [2], a potential enzyme producer seen from the highest hydrolysis index compared to others. [13], states that isolates that produce a clear zone diameter twice the diameter of a colony are potential enzyme production.

Each bacterium has a different strategy. The amount of final results obtained in the degradation process depends on several factors, namely $\mathrm{pH}$, access to carbon (enzyme conformation with substrate conformation), redox reaction that occurs, product concentration, [14]. Cellulolytic potential can also be known in secreting cellulase enzymes through cellulolytic index testing based on clear zones visible around CMC Carboxy methyl cellulose colonies, [15].

The degradation test using clear zone method is a semi test because the data is only in the form of a comparison between the diameter of the clear zone and the diameter of the colony. The difficulty of this method is if the resulting colony or clear zone is not really round, or even not round at all. [16] also mentions that the clear zones formed are related to the solubility of the cellulase enzyme. The higher the solubility level of an enzyme, the greater the clear zone is formed

\section{Conclusions}

From the results of this study obtained 6 isolates of cellulolytic bacteria. Based on the qualitative test, the highest clear zone index was found in B3 isolates of 1,201 mm which potentially degraded cellulose

\section{Reference:}

[1] BPS Sumatera Utara. 2016. Sumatera Utara Dalam Angka. Badan Pusat Statistika.

[2] Yunilas, L. Warly, Y. Marlida, and I. Riyanto. 2013. Potency of Indigenous Bacteria from Oil Palm Waste in Degrades Lignocellulose as A sources of Inoculum Fermented to High Fibre Feed. Pakistan Journal of Nutrition.

[3] Coughlan, M. P. 1985. The Properties of Fungal and Bacterial Cellulases With Coment On Their Production And Application. Biotechnol Gen Rey 3:39-109

[4] Kluepfel, D. 1988. Screening of Prokaryotes for Cellulose and Hemicelulloses Degrading Enzymes. Methods Enzymology.

[5] Lay, W. B. 1994. Analisa Mikroba di Laboratorium Edisi I. Raja Grafindo Persada. Jakarta.

[6] Cappucino, J. G., and Sherman, N. 1987. Microbiology: A Laboratory Manual. The Benjamin/Cummings Publishing Company, Inc. California

[7] Steel, R. G. D., dan J. H. Torrie. 1995. Prinsip dan Prosedur Statistika. Penerjemah Bambang Sumantri. Gramedia Pustaka. Jakarta.

[8] Dwidjoseputro, D. 2005. Dasar-Dasar Mikrobiologi. Djambatan. Malang.

[9] Meryandini, A., Widosari, W., Maranatha, B., Sunarti, T.C., Rachmania, N., dan Satria, H. 2009. Isolasi Bakteri selulolitik dan Karakterisasi Enzimnya. IPB. Bogor

[10] Ali, A. 2005. Mikrobiologi dasar. State University of Makassar Press. Makassar.

[11] Hartanti. 2010. Isolasi dan Seleksi Bakteri Selulolitik Termofilik dari Kawah Air Panas Gunung Pancar. FMIPA IPB. Bogor.

[12] Sari, M., Agustien, U dan Nurmiati, A. 2012. Screening and characterization of cellulolytic thermophylic bacteria from Sungai Medang hot spring, Kerinci, Jambi. Jurnal Biologi Universitas Andalas.

[13] Ochoa-Salano, J. And Olmos-Soto,J. 2006. The functional property of Bacillus for shrimp feeds. Food Microbiology 
[14] Ambriyanto, S K. 2010. Isolasi dan Karakterisasi Bakteri Aerob Pendegradasi Selulosa dari Serasah Daun Rumput Gajah (Pennisetum Purpureum Schaum). Jurusan Biologi Fakultas Matematika Dan Ilmu Pengetahuan Alam Institut Teknologi Sepuluh Nopember.

[15] Zahidah, D. dan Shovitri, M . 2013. Isolasi, Karakterisasi dan potensi Bakteri Aerob sebagai Pendegradasi Limbah Organik. Jurnal Sains dan Seni Pomits.

[16] Zverlova, V V., Holl, W., and Schwarz, H. 2003. Enzymes for digestion of cellulose and other polysaccharides in the gut of longhorn beetle larvae, Rhagium inquisitor L. (Col., Cerambycidae). International biodeterioration \& biodegradation. 